•研究报告・

\author{
新疆山地森林乔木和草地草本植物 \\ 个体大小分布特征 \\ 李利平 $1^{*}$ 安尼瓦尔. 买买提 ${ }^{2}$ 努尔巴依. 阿布都沙力克 ${ }^{3}$ \\ 努尔佳玛丽. 沙尔巴依 ${ }^{3}$ 万华伟 ${ }^{4}$ \\ 1 (中国科学院遥感与数字地球研究所, 北京 100101) \\ 2 (中国科学院新疆生态与地理研究所, 乌鲁木齐 830011) \\ 3 (新疆大学资源与环境科学学院绿洲生态教育部重点实验室, 乌鲁木齐 830046) \\ 4 (环境保护部卫星环境应用中心, 北京 100094)
}

\begin{abstract}
摘要: 个体大小是植物重要的特征之一, 目前其受环境因子的影响还不十分清楚。基于样地实际调查数据, 我们 分析了新疆山地森林乔木和草地草本植物个体大小的特征(统称为乔木和草本, 分别以平均胸径和平均株高表示), 并在物种和区域尺度, 分析了其与分布区特征和植物多样性的关系。研究发现: (1)在物种尺度上, 森林植被中乔木 物种的个体大小与其分布区特征正相关, 即分布范围较广的乔木倾向于个体更大; 草地植被中草本植物的特征与 此类似; (2)在区域尺度上, 乔木平均个体越大, 区域植物平均分布区越小, 反之亦然; 草本植物的平均个体大小与 区域植物分布区特征无显著相关性; (3) 在区域尺度上, 森林乔木和草地草本植物的个体大小与植物多样性均呈正 相关关系，即森林乔木和草地草本植物平均个体较大时，其区域多样性更高。
\end{abstract}

关键词：植物个体大小；植物分布区；物种尺度；区域尺度；植物多样性；新疆

\title{
Plant body size patterns of mountainous trees and grassland herbs in Xinjiang region, China
}

\author{
Liping $\mathrm{Li}^{1 *}$, Anwar Mohammat ${ }^{2}$, Nurbay Abdusalih ${ }^{3}$, Nurjamal Sarbay ${ }^{3}$, Huawei Wan $^{4}$ \\ 1 Institute of Remote Sensing and Digital Earth, Chinese Academy of Sciences, Beijing 100101 \\ 2 Xinjiang Institute of Ecology and Geography, Chinese Academy of Sciences, Urumqi 830011 \\ 3 Key Laboratory of Oasis Ecology of Ministry of Education, College of Resources and Environmental Sciences, Xinjiang \\ University, Urumqi 830046 \\ 4 Satellite Environment Center, Ministry of Environmental Protection, Beijing 100094
}

\begin{abstract}
Species body size is an important trait, however, currently the correlations of body size with range size and species richness are still not very clear, especially for plants. With plant distribution and plot investigation data in the Xinjiang region of China, we explored plant body size patterns and tested the relationship between plant body size and range size, both at the species and regional scale. Further, the relationship of plant body size and plant richness was also tested at the regional scale. In this study, tree body size of forests was indicated using the average diameter at breast height (DBH), and the herbaceous plant body size of grasslands was indicated using the average height based on our plot investigation. Regional plant body size was the average value of all measured plants distributed in each grid cell $\left(0.1^{\circ} \times 0.1^{\circ}\right)$. We found that: (1) At the species scale, tree body size was positively correlated with range size characteristics, i.e., trees that spread wider were normally larger in size than those in narrower ranges; herb body size displayed a similar pattern with lower correlation coefficients; (2) At the regional scale, a region with larger average tree body size tended to have lower regional average plant range size and vice versa; the regional herb body size of grasslands did not significantly correlate with
\end{abstract}

收稿日期: 2016-11-24; 接受日期: 2017-10-23

基金项目: 国家自然科学基金(81503183, 81560660, 41561013, 41273098)

* 通讯作者 Author for correspondence. E-mail: lilp@radi.ac.cn 
the regional average plant range size; (3) At the regional scale, tree body size and herb body size both positively correlated with regional plant richness. We concluded that at the species and regional scale, for different vegetation, the plant body size may have different patterns and correlate differently with range size characteristics.

Key words: plant body size; plant range size; species scale; regional scale; plant richness; Xinjiang

个体大小(body size)是生物体一个非常明显的 特征, 该值受诸多环境因子的影响, 反过来也影响 生物体的功能和进化(LaBarbera, 1989)。早在19世纪 中期，贝格曼就阐述了动物个体大小与纬度的关系， 即贝格曼法则(Bergmann, 1847)。此外, 物种的分布 区大小(range size)、区域生物多样性等在不同的纬 度或环境下有很大不同, 也有可能影响生物的个体 大小(Blackburn \& Gaston, 1996a)。目前, 物种个体 大小仍然是大尺度物种分布研究中非常重要的研 究对象, 而由于不同研究采用的数据尺度和分辨率, 以及个体大小计量方法等不同, 个体大小与环境因 子和多样性之间的相关关系并不确定 (Gaston \& Blackburn, 1996; White et al, 2007)。个体大小及其随 环境因子的变化研究在哺乳动物和鸟类(Blackburn \& Gaston, 1996a, b; Willig et al, 2003; Blackburn \& Hawkins, 2004; Olson et al, 2009)中相对较多, 而受 限于基础数据缺乏, 在昆虫(Siqueira et al, 2008; 毕 孟杰等, 2015; 匡先钜等, 2015)及植物(Tracey \& Aarssen, 2011)等类群中的研究较为少见。

对于植物, 较早的研究集中在一些类群或较小 的区域(例如Wilson \& Gurevitch, 1995; Thompson et al, 1999)。随着生物地理学的发展, 有越来越多的地 理信息、综合分析和统计技术可以用在相关的研究 中, 可以开展更高分辨率下更大区域(洲际及全球)、 更多物种及种类的研究并进行对比 (Moles et al, 2009; Díaz et al, 2016; Zhang et al, 2016)。Díaz等 (2016)通过对影响全球维管束植物生长、存活和繁 殖的主要特征进行分析发现, 这些特征大部分可以 被归并为两类, 一类是植物体及其部分(如叶、茎、 种子)的大小, 另一类是叶经济谱。叶经济谱表示了 植物叶片的构建消耗和生长潜能之间的平衡, 而植 物的个体大小则表征了植物生长中诸多因子的协 调(coordination)。

一般来说, 生物量是度量植物个体大小的一个 较为精确的指标(Weiner \& Thomas, 1986), 也有研 究者采用树高、胸径或种子大小等一些指标近似代
替生物量/植物个体大小(Fang et al, 2006; 王希华, 2006; Moles et al, 2009)。植物个体一般是大个体较 少、小个体较多的右偏分布(right-skewed distribution), 这个分布特点在种内(Weiner \& Thomas, 1986) 和种间(Aarssen et al, 2006; Tracey \& Aarssen, 2014) 均存在。目前, 植物个体大小与其地理分布及分布 区大小关系如何, 在物种和区域尺度上的格局特征 是否一致还没有明确的结论。本文基于新疆地区森 林和草地的实地样地调查数据, 分别以森林植被中 乔木的平均胸径和草地植被中草本植物的平均株 高代表植物个体大小, 计算了该地区植物个体大小 的特征, 同时结合区域生物多样性分布本底数据, 探讨了区域尺度上植物个体大小与其地理位置、分 布区大小及区域植物丰富度的关系。

\section{1 材料与方法}

\section{1 研究区概况}

新疆地区地处欧亚大陆腹地, 冬季处于西伯利 亚-蒙古高气压的中心, 气候干冷; 由于距海遥远, 夏季海洋季风难以深入, 干旱少雨, 所以为典型的 内陆干旱区, 热量条件相对充足而水分缺乏, 寒暑 剧变, 降水变率很大(李江风, 1991)。根据我国气候 系统区划, 新疆大部分地区属于中温带 $\left(\geq 10^{\circ} \mathrm{C}\right.$ 年积 温 $1,600-3,200 / 3,400^{\circ} \mathrm{C}$ )。按年降水量的多少, 又将 天山区、阿尔泰山区、伊犁区划定为亚干旱区(年干 燥系数1.6-3.5), 和布克赛尔区、乌恰-阿合奇区、 塔城区、额尔齐斯一乌伦古河区、准噶尔盆地划定 为干旱区(年干燥系数3.5-16.0) (中国科学院中国自 然地理编辑委员会, 1985)。大体上, 新疆地区由于 天山(海拔高度一般4,000-5,000 m, 南北宽 250$300 \mathrm{~km}$, 东西全长 $2,500 \mathrm{~km}$, 在新疆境内 $1,700 \mathrm{~km}$ ) 的阻隔作用形成了南疆和北疆两个不同的气候区。 由于南部青藏高原和北部天山的阻挡, 湿润气流难 以进入, 导致南疆水分缺乏, 环境严酷, 而北疆受 大西洋及北冰洋气团的影响, 水分相对充足。

新疆地区主要的植被类型为荒漠和草地, 森林 
面积不大。其中草地和森林主要分布在山地, 荒漠 植被主要分布在盆地, 塔里木盆地和吐哈盆地还有 大面积的无植被区。新疆山地有乔木建群种 23 种, 灌木建群属 8 个。乔木物种主要是西伯利亚落叶松 (Larix sibirica)、西伯利亚云杉(Picea obovata)、西 伯利亚冷杉(Abies sibirica)、西伯利亚红松(Pinus sibirica)、雪岭云杉(Picea schrenkiana)、昆仑方枝柏 (Juniperus centrasiatica)、昆仑圆柏(J. jarkendensis)、 新疆方枝柏(J. pseudosabina)、垂枝桦(Betula pendula)、天山桦(B. tianschanica)和欧洲山杨(Populus tremula), 还有一些野果林如新疆野苹果(Malus sieversii)、野杏 (Armeniaca vulgaris) 和野核桃 (Juglans regia), 及山地河谷中的小叶白蜡(Fraxinus sogdiana)、苦杨 (Populus laurifolia) 和额河杨 (Populus $\times$ jrtyschensis)等(中华人民共和国林业部, 1989)。在20世纪50-60年代, 在山区进行过一些强 度较大的伐木活动, 近几十年来, 根据国家政策, 实施了天然林保护工程。

\section{2 数据来源}

物种个体大小基于实地样地调查数据(安尼瓦 尔 - 买买提, 2006; 王磊等, 2006; 李利平, 2010)进 行计算, 区域的本底多样性数据来自于根据地区植 物志整理的数据集(李利平, 2010), 该数据集包含了 新疆地区分布的野生维管束植物 3,637种, 植物分 布区数据主要参考李利平等(2017)。新疆地区植物 在其他区域的分布较难获取, 所以, 本文中植物分 布区仅考虑了这些物种在新疆本地的分布。

样地调查主要于2003-2007年的7-9月进行, 样 方的地理分布详见Li等(2015)。森林样地优先选择均 一的成熟林, 尽量避免人为干扰, 至少要避免近期 的人为干扰。森林样地大小为 $20 \mathrm{~m} \times 30 \mathrm{~m}$, 主要记 录样地内所有物种的名称, 测量乔木植株的胸径 (胸径 $\geq 4 \mathrm{~cm}$ ) 和树高。针叶林调查范围包括了天山、 阿尔泰山和昆仑山等 11 个区域, 共获取针叶林样地 调查数据 122 份; 阔叶林(主要为野果林)主要分布 在伊犁地区, 共获取样地调查数据67份。在所有森 林样地中共计调查到 18 种乔木, 包括7种裸子植物 和11种被子植物, 裸子植物分别是西伯利亚冷杉、 西伯利亚云杉、西伯利亚落叶松、西伯利亚红松、 雪岭云杉、新疆方枝柏和昆仑圆柏; 被子植物分别 是欧洲山杨、黄花柳(Salix caprea)、谷柳(S. taraikensis)、野核桃、垂枝桦、白榆(Ulmus pumila)、
准噶尔山楂(Crataegus songorica)、天山花楸(Sorbus tianschanica)、新疆野苹果、野杏和樱桃李(Prunus sogdiana)。

草地样地也选择较为典型的区域, 避免人为干 扰。草地样地大小为 $1 \mathrm{~m} \times 1 \mathrm{~m}$, 主要测量样地内草 本植物的株高, 对于在一个样地内重复出现的物种, 估算其平均株高。草地调查共获取样地调查数据 103份，包括了草甸草原、高寒草甸、高寒草原、荒 漠草原、山地草甸和温性草原等类型。草地样地共 计调查到约 367 种植物, 主要为禾本科、菊科、莎草 科和蓄薇科植物, 如嵩草属(Kobresia)、针茅属 (Stipa)、风毛菊属(Saussurea)、薹草属(Carex)和委 陵菜属(Potentilla)等。

\section{3 数据分析}

对于乔木来说, 树高与生物量有很强的相关性 (Fang et al, 2006), 可以表征植物的个体大小。但在 实地调查中, 其测量结果不如胸径精确, 所以本研 究采用胸径来表征乔木物种的个体大小; 对于草地 草本植物, 采用株高表征其个体大小。需要说明的 是, 受林冠层的影响, 森林植被中林下分布的草本 植物个体大小差异较大，在本文的分析中未包括， 本文所指草本植物仅是草地植被中的草本植物, 在 后文中统一简称为草本植物。

将样地调查中涉及到的乔木平均胸径/草本株 高分别作为乔木和草本植物的个体大小, 分析该数 据集的频度分布特征，分析其地理格局(即与物种 分布的经纬度的关系)及其与物种分布区特征的关 系。物种分布区特征以物种所占据的栅格 $\left(0.1^{\circ} \times\right.$ $0.1^{\circ}$ )数来表征, 包括物种的分布区面积(range area, $R A) 、$ 东西分布幅度(extent East-West, extent EW) 和 南北分布幅度(extent North-South, extent NS)。物种 分布区的具体计算过程如下：(1)收集新疆地区分布 的所有维管束植物的县级分布信息及其海拔范围; (2)按照WGS1984坐标系, 将新疆全区划分为 $0.1^{\circ} \times$ $0.1^{\circ}$ 的栅格, 结合美国USGS发布的 $0.0083^{\circ}$ 分辨率 DEM数据, 得到每个 $0.1^{\circ} \times 0.1^{\circ}$ 栅格的海拔范围; (3) 将区域内分布的所有维管束植物的县级分布及其 海拔范围与栅格的属性(经纬度和海拔范围)进行叠 加, 滤掉没有分布的区域, 得到基于栅格的每个物 种的分布图，也就是每个物种在地理上的分布范围; (4)按照每个物种的分布范围, 计算其所分布的栅格 总数即 RA，计算其东西向所占据的栅格数作为 


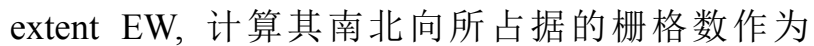
extent NS。关于新疆地区物种分布区特征更详细的 研究见李利平等(2017)。物种分布的经/纬度值以其 分布的经/纬度范围的中点值表示, 如某物种分布 在 $80.3^{\circ}-90.3^{\circ} \mathrm{E}, 41.2^{\circ}-45.2^{\circ} \mathrm{N}$, 则认为该物种分布 的经 $/$ 纬度值为 $85.3^{\circ} \mathrm{E}$ 和 $43.2^{\circ} \mathrm{N}$ 。

将物种个体大小在栅格尺度 $\left(0.1^{\circ} \times 0.1^{\circ}\right)$ 进行 平均, 即将出现在某一栅格的所有调查到的物种的 个体大小值进行平均, 作为栅格(即区域尺度)植物 个体大小, 以研究区域尺度上植物个体大小与分布 区及丰富度的关系。本文中区域的分布区特征是指 区域(即栅格)内分布的所有植物的分布区特征的中 值; 同样地，区域植物丰富度指区域(即栅格)内分布 的所有植物的种类数, 而非仅样地调查涉及的植物。

除了 $0.1^{\circ} \times 0.1^{\circ}$ 的栅格大小, 本文在 $0.2^{\circ} \times 0.2^{\circ}$ 栅格大小下重复了所有的计算, 在两个分辨率下, 物种个体大小及与环境因子的关系基本趋势一致, 因此在正文中仅体现 $0.1^{\circ} \times 0.1^{\circ}$ 的结果, 区域尺度 $0.2^{\circ} \times 0.2^{\circ}$ 的结果作为附录(附录 $\left.1,2,3\right)$ 。

所有的样地数据和物种分布数据用 Microsoft
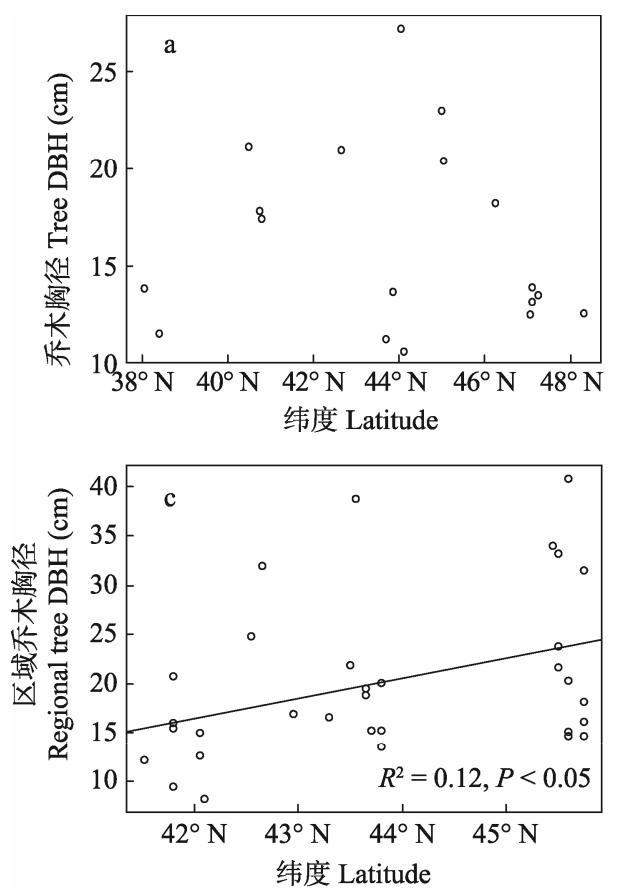

SQL Server 2016 Express数据库进行管理和计算, 用ArcGis 10.3进行地理制图, 用R 3.3.1 (R Core Team, 2016)进行回归统计分析和制图。

\section{2 结果}

\section{1 植物个体大小的地理分布}

植物个体大小为右偏分布, 乔木胸径和草本植 物株高的偏度系数分别为 0.69 和 1.80 , 小个体较多 而大个体较少。乔木个体大小与其分布区域经纬度 的中值无显著相关关系 $(P>0.05$; 图 $1 \mathrm{a}, \mathrm{b})$, 即在新 疆地区，乔木物种个体大小与其所分布的区域无关。 在区域上(栅格平均), 乔木的平均个体大小随纬度 和经度的增加有升高趋势 $(P<0.05$, 图 $1 \mathrm{c}, \mathrm{d})$ 。

对于草本植物，随着纬度升高，其平均株高有 微弱降低趋势 $(P<0.05$, 图 $2 \mathrm{a})$, 而其随经度的变化 不显著 $(P>0.05$, 图 $2 b)$; 在区域尺度上, 草本植物 平均株高随纬度的升高也有降低趋势 $(P<0.05$, 图 $2 \mathrm{c})$, 而随经度的变化不显著 $(P>0.05$, 图 $2 \mathrm{~d})$ 。

\section{2 植物个体大小与其分布区特征的关系}

回归分析结果表明，乔木物种的平均胸径和
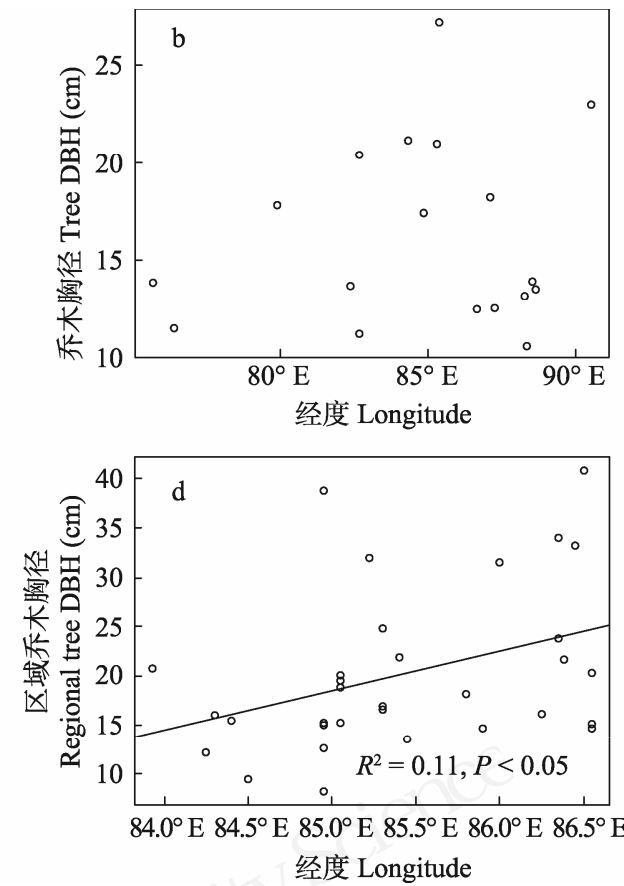

图1 森林乔木物种个体大小与其分布经纬度(物种尺度, a, b)及栅格水平平均个体大小与物种分布经纬度(区域尺度, $\mathrm{c}, \mathrm{d}$ )的 关系。在物种尺度, 取物种分布的经纬度范围的中点作为该物种分布的经纬度; 在区域尺度, 取所有在该栅格中出现的物种 的经纬度中点的中值作为栅格的经纬度值。

Fig. 1 Relationship of tree DBH (diameter at breast height, $\mathrm{cm}$ ) of forests and the plant spatial distributions (latitude and longitude) both in species and regional scale. In the species scale, the plant spatial distribution value is the midpoint of a species geographic range; and in the regional scale, the plant spatial distribution value of a grid cell is the median value of the geographic midpoints of all the plants that appear in it. 

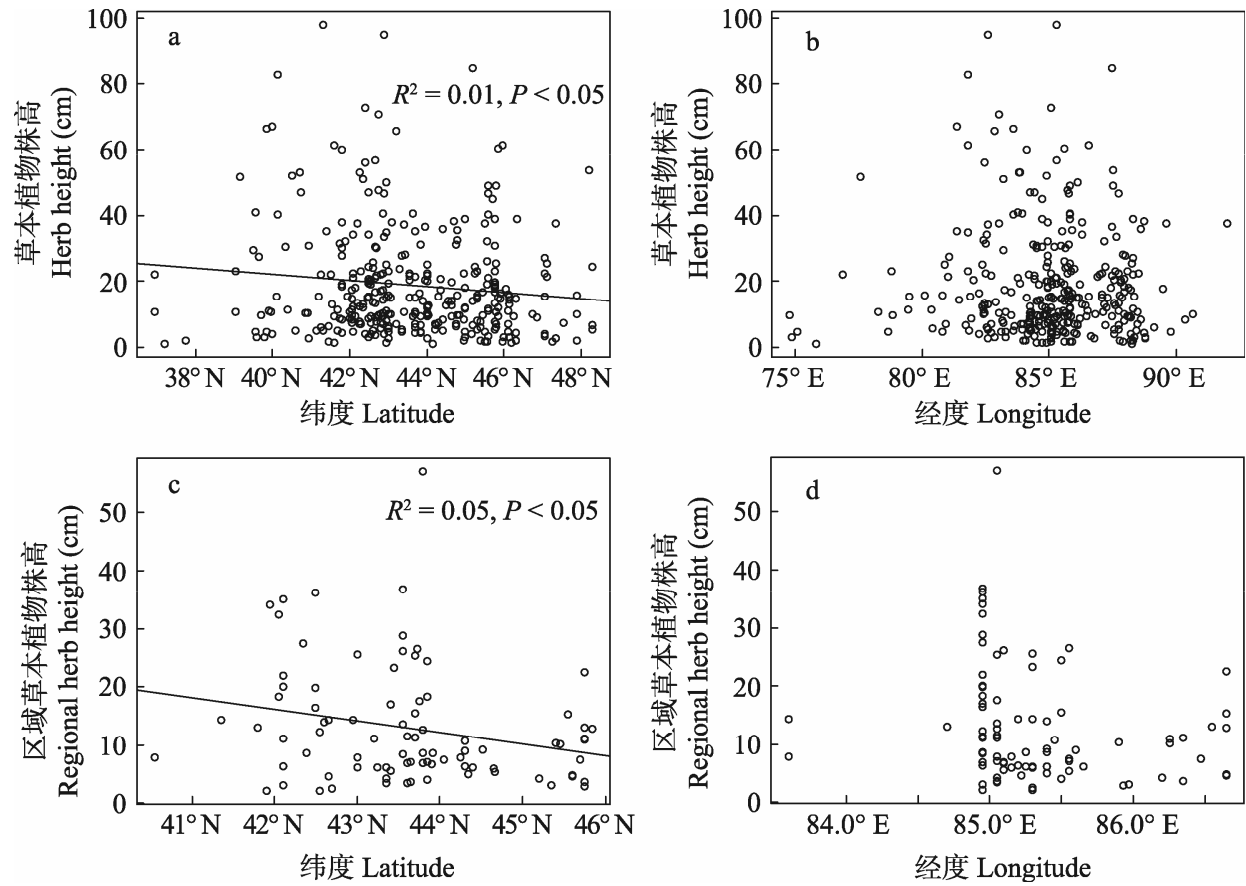

图2 草地草本植物个体大小与其分布经纬度(物种尺度, a, b)及栅格水平平均个体大小与物种分布经纬度(区域尺度, $\mathbf{c}, \mathbf{d}$ )的 关系。在物种尺度, 取物种分布的经纬度范围的中点作为该物种分布的经纬度; 在区域尺度, 取所有在该栅格中出现的植物 种的经纬度中点的中值作为栅格的经纬度值。

Fig. 2 Relationship of herbaceous plant height $(\mathrm{cm})$ of grasslands and the plant spatial distributions (latitude and longitude) both in species and regional scale. In the species scale, the plant spatial distribution value is the midpoint of a species geographic range; and in the regional scale, the plant spatial distribution value of a grid cell is the median value of the geographic midpoints of all the plants that appear in it.

其分布区面积、南北分布幅度及东西分布幅度呈显 著正相关关系 $(P<0.05$, 图 $3 \mathrm{a}, \mathrm{b}, \mathrm{c})$ 。分布范围和个 体较大的物种是西伯利亚落叶松、欧洲山杨和白榆 等; 而分布范围小且个体较小的物种是天山花楸、 黄花柳和樱桃李等; 分布范围和个体大小都处于中 等的物种是昆仑圆柏和谷柳等。然而在区域尺度上, 栅格内物种个体大小与分布区/南北分布幅度之间 呈负相关关系 $(P<0.05$, 图3d, e $)$, 即在区域尺度, 森林平均乔木物种个体越大, 整个区域分布的植物 种的平均分布区越小。这个结果与图 $3 a, b$ 的趋势相 反, 即物种个体大小在物种尺度与区域尺度随分布 区面积及南北分布幅度的变化趋势相反。栅格内物 种个体大小和东西分布幅度无显著相关关系 $(P>$ 0.05 , 图3f)。

草地草本植物的平均株高与其分布区面积无 显著相关关系 $(P>0.05$; 图 $4 a)$, 与南北和东西分布 幅度之间的关系在统计上显著 $(P<0.05$, 图 $4 b, c)$ 。 在区域尺度上, 未发现草地草本植物的株高与区域 植物分布幅度各项特征有显著相关关系 $(P>0.05$; 图4d, e, f)。

\section{3 植物个体大小与植物丰富度的关系}

对区域植物个体大小和植物丰富度进行回归 分析发现，区域植物丰富度越高，乔木物种平均胸 径越大 $(P<0.05$, 图 $5 \mathrm{a})$, 草本植物的株高越大 $(P<$ 0.05 , 图5b)。以天山地区伊犁谷地为例，该区域整 体的植物丰富度较高, 森林乔木平均个体较大，区 域植物的平均分布区面积较小; 反之, 在一些气候 条件较差的区域, 可能整体丰富度较低, 森林乔木 平均个体较小，区域内植物的平均分布区面积较 大。草地草本植物个体大小特征与之类似, 在植物 丰富度较高的区域, 平均个体较大。

\section{3 讨论}

\section{1 物种个体大小及其地理分布特征}

物种的个体大小是其最基本的特征之一，与生 活史、栖息地范围等密切相关(White et al, 2007), 也 决定了一系列其他的物种特征, 影响食物链的结构 和动态等, 从而对整个群落造成影响(Woodward et $\mathrm{al}, 2005)$ 。较早关注生物体的个体大小是在动物研 究中，贝格曼法则(Bergmann， 1847)阐述了恒温脊 
椎动物的个体大小, 认为其在寒冷气候中的体型比 在温暖环境中大, 也就是说同一种类的恒温脊椎动 物，地理上分布在北方的个体比分布在南方的大。 后来关于物种个体大小的研究扩展到了物种的分 布区地理格局等, 如Rapoport法则(Stevens, 1989)认
为物种的分布区范围随纬度升高而增大。

一般认为, 物种个体越大, 其对资源的竞争力 越强(Brown \& Maurer, 1986)。从这个角度来看, 物 种应该倾向于更大，而实际情况是群落中物种的个 体大小分布多为右偏，即更多的物种个体偏小，新
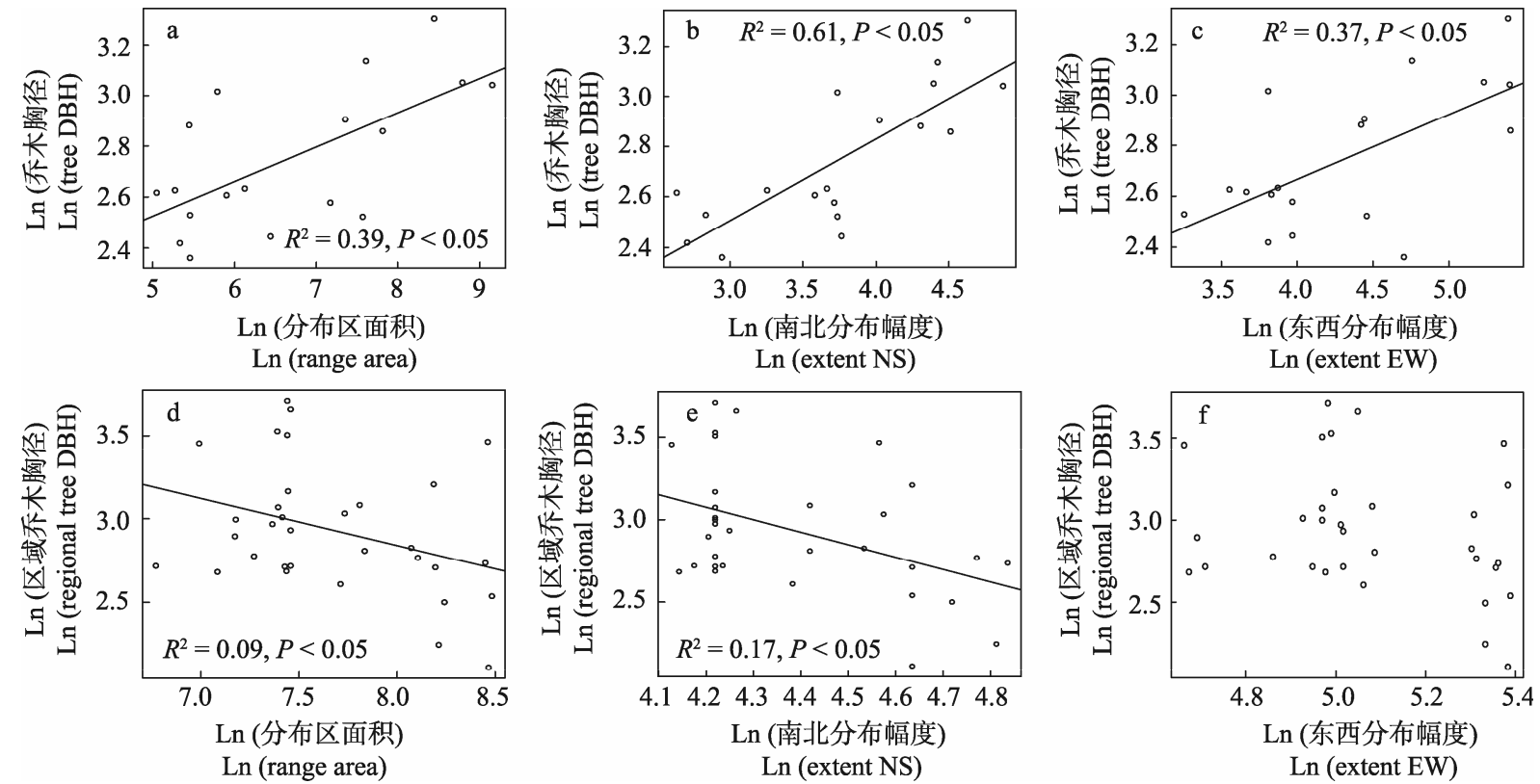

图3 森林乔木物种个体大小与分布区特征(分布区面积、南北分布幅度、东西分布幅度)的关系(自然对数, a, b, c为物种尺度, $\mathbf{d}, \mathbf{e}, \mathbf{f}$ 为区域尺度)

Fig. 3 Relationship of DBH (diameter at breast height, $\mathrm{cm}$ ) of trees in forests and species range size (range area, extent North-South (extent NS) and extent East-West (extent EW)). Logarithmic scale with a, b, c of species and d, e, f of regional scale.
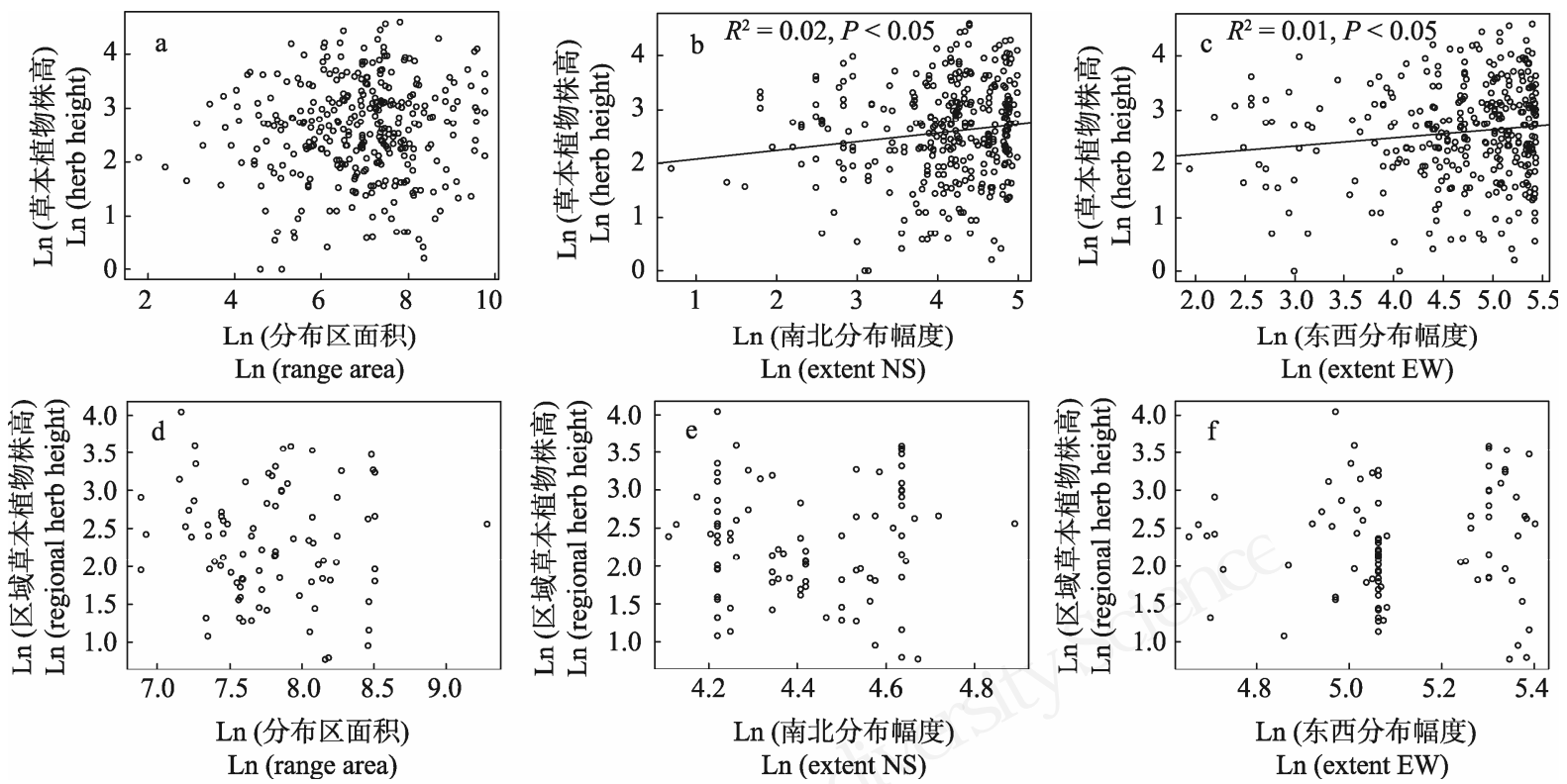

图4 草地草本植物个体大小与分布区特征(分布区面积、东西分布幅度、南北分布幅度)的关系(自然对数, a, b, c为物种尺 度, $d, e, f$ 为区域尺度)

Fig. 4 Relationship of height of herbaceous plants $(\mathrm{cm})$ in grasslands and species range size (range area, extent North-South (extent NS) and extent East-West (extent EW)). Logarithmic scale with a, b, c of species scale and d, e, f of regional scale. 

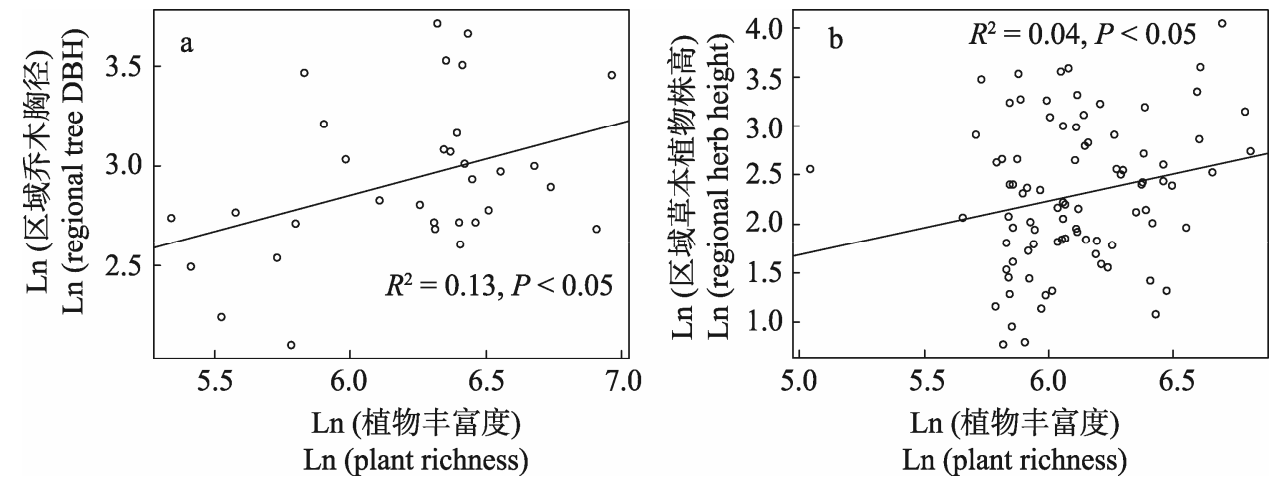

图5 区域森林乔木和草地草本植物个体大小与物种丰富度的关系(自然对数)

Fig. 5 Relationship of regional plant body size and species richness (with logarithmic scale)

疆地区的森林乔木和草地草本植物也均是小个体 多的右偏分布。有研究者认为小个体物种有繁殖及 分化优势(Aarssen et al, 2006; Tracey \& Aarssen, 2011), 在极端环境条件下, 由于竞争, 大个体的物 种可能在产生后代(如种子)之前死亡, 小个体的物 种以较小的个体达到成熟, 至少可以产生一些后代 (Aarssen, 2015); 在占据同样空间的情况下, 较多的 小个体物种可能会比少数大个体物种所产生的后 代更多(Tracey et al, 2016)。另外，大个体物种的种 内竞争压力会更大(Schamp \& Aarssen, 2014), 且更 易被取食(尤其是花), 这可能会抵消其个体大的竞 争优势(Schlinkert et al, 2015)。由于植物群落中小个 体的物种总是相对较多(Aarssen et al, 2006), 一些 研究者甚至认为小个体是一些物种的进化方向 (Dombroskie \& Aarssen, 2010)。植物的竞争优势不 只体现在其个体大小, 对严酷环境的适应及繁殖能 力也非常重要(Waugh \& Aarssen, 2012; Tracey \& Aarssen, 2014)。繁殖能力包括了后代的数量及其传 播方式等诸多特征。这一点在更早的研究中得到过 部分验证, 如McGlone等(2010)对新西兰乔木的研 究发现由鸟类传播种子的乔木物种分布范围更宽。

Moles等(2009)将所有的植物合并分析，不区 分乔/灌/草/藤生活型, 研究了全球植物的株高特 征, 发现植物的最大株高存在明显的地理格局, 纬度 $0^{\circ}-15^{\circ}$ 之间的平均最大株高 $(7.8 \mathrm{~m})$ 是 $45^{\circ}-60^{\circ}$ 之间平均最大株高 $(0.25 \mathrm{~m})$ 的 31 倍, 低纬度地区明 显高于高纬度地区。Zhang等(2016)分析了全球森 林冠层(也即乔木最大株高)的格局, 也发现了低纬 度地区较高的现象。与纬度梯度类似，在海拔梯度 上, 最大树高也存在一些规律, Mao等(2017)发现在
青藏高原地区，被子植物的最大树高随海拔的升 高而降低。

理论上，对于乔木来说，最大胸径/最大树高可 能更能代表其个体大小, 但是在本研究中, 由于在 实地调查中发现较多大树的砍伐痕迹，同时，胸径 的测量相比树高更容易也更准确，所以选择了平均 胸径作为个体大小的表征。我们对最大胸径也进行 了相同的计算, 与平均胸径相比, 其与各项因子的 关系总体趋势不变，回归系数略低。

在区域尺度上，新疆地区乔木的个体大小与 纬度为正相关, 这可能与新疆地区独特的地理环 境及森林的分布有关：整体上，北疆阿尔泰山、天 山北坡的水分等条件优于天山南坡及昆仑山，可 能造成了北部乔木个体较大。对于草本植物来说, 在物种和区域尺度上, 其个体大小与纬度都呈负相 关，就是说分布在更北部区域的草本植物个体更小, 且区域尺度上平均的北部地区草地草本植物个体 整体上也较小。对比森林和草地这两种不同的植被 类型，其乔木和草本植物个体大小与地理分布的关 系并不相同。Li等(2015)对该区域植物丰富度的研 究也发现了森林和草地的不同地理格局: 森林植物 丰富度随纬度的升高而升高，而草地植物丰富度随 纬度的升高而降低。

\section{2 物种个体大小与分布区大小的关系}

关于物种个体大小和分布区的关系在动物中 研究较多,一般认为动物个体大小和分布区面积为 正相关关系。Juliano (1983)对北美Brachinus属步甲 的研究发现, 个体大小和扩散能力与其分布区大小 正相关，扩散能力弱(不会飞)的物种的分布区范围 小于扩散能力强(会飞)的物种。Bowers和Brown 
(1982)对荒漠齿齿类的个体大小进行研究发现, 种 间竞争导致个体大小相近的物种不共存。Blackburn 和Gaston (1996b) 对美洲大陆鸟类, Fernandez和Vrba (2005)对非洲大型哺乳动物的研究均发现, 个体小 的物种有大的或者小的分布区, 而个体较大的物种 一般只能有大的分布区。Fernandez和Vrba (2005)还 认为小个体和大个体的物种是进化上的专有种 (biomic specialists), 中等大小的物种应该最多。动 物个体大小随分布区面积的变化存在增加、减小或 者没有显著相关关系三种情形, Gaston和Blackburn (1996)认为, 综合的研究中物种个体大小和分布区 范围正相关, 但是包括的地理范围不够宽或物种不 够多的研究中物种个体大小和分布区范围的关系 正负相关的情况都有。Madin和Lyons (2005)分析了 取样对物种个体大小和分布区面积大小相关性的影 响, 结果发现不完全的取样造成了两者相关性的不 确定, 因为不完全的取样使得大分布范围物种的分 布范围偏低, 并且完全忽略掉了小分布范围的物种。

McGlone等(2010)对新西兰的乔木特征包括个 体大小、地理分布、分布区大小、物种丰富度、叶 特征等进行了总结, 并与欧洲、北美等区域进行了 对比。该研究发现新西兰乔木分布范围较窄 $\left(1^{\circ}-3^{\circ}\right)$ 的物种的平均高度为 $8.8 \pm 0.6 \mathrm{~m}$, 然而分布范围较 宽 $\left(11^{\circ}-13^{\circ}\right)$ 的物种的平均高度为 $11.8 \pm 1.0 \mathrm{~m}$, 分布 范围较大, 树种的树高更高。与上述研究类似, 本研 究对新疆地区的植物个体大小进行分析也发现, 在 物种尺度, 植物的个体大小 (乔木胸径和草本植物 株高)与其分布区特征呈正相关, 即个体较大的物 种有更大的分布区，尤其是对森林乔木物种来说。

在本研究中, 限于物种分布数据本身主要是来 自于新疆地区的植物志, 物种的分布未能扩展到我 国的其他省份和国外地区，这可能会造成数据不够 准确。但是实际调查所涉及的物种, 尤其是乔木种, 如新疆野苹果、野杏、野生樱桃李等物种的主要分 布区就是伊犁地区, 所以这部分物种在新疆的分布 区可以近似代表其实际的分布区。另外，根据经验 判断, 所调查物种分布范围的相对大小符合实际情 况, 如广布种白榆, 其分布范围较大, 欧洲山杨、雪 岭云杉、西伯利亚落叶松等分布范围也较大; 而野 果林物种, 如新疆野苹果、野杏、野生樱桃李等分 布范围较小。也有部分物种的分布区数据与实际不 太相符, 如由于未能包括在俄罗斯等国家的分布,
计算得到的西伯利亚冷杉、西伯利亚云杉等的分布 范围偏小。总体上, 新疆地区本身面积较大, 天山、 塔里木盆地、准噶尔盆地等植物区系也很独特, 所 以我们认为基于新疆地区本身的数据在很大程度 上代表了这些物种的分布区特征, 多数物种的分布 范围数据可信。

\section{3 区域尺度植物个体大小与分布区、植物丰富度 的关系}

一般来说, 由于小生境等因素, 植物和其相邻 个体的大小呈正相关 (Garcia，2006)。Wilson和 Gurevitch (1995)在小尺度上 $(700 \mathrm{~cm} \times 20 \mathrm{~cm}$ 样带) 对一种勿忘草属短生植物 Myosotis micrantha的研 究认为, 不同物种个体大小的分布具有正的空间自 相关, 个体较大的物种倾向于与个体较大的其他物 种共存; 植物密度的不同和资源的斑块分布造成了 植物的个体大小不同, 同种植物种内竞争较大(密 度大)和较差的环境导致植物个体较小。

在大尺度上, Rapoport法则描述了植物分布区 的纬度梯度, 被广为接受(沈泽昊和卢绮妍, 2009)。 有许多学者对该法则进行了验证，如McGlone等 (2010)对新西兰的乔木个体大小与其分布区、植物 丰富度的关系进行了研究, 发现纬度越高, 乔木的 分布区越大, 物种丰富度越低, 与Rapoport法则一 致。除了纬度梯度, 该法则还被许多研究扩展到海 拔梯度上(卢绮妍和沈泽吴, 2009)。本研究对新疆地 区森林乔木和草地草本植物的研究发现, 平均个体 较大, 则区域植物多样性较高(图5), 区域尺度上, 所有植物平均的分布区较小(图3)。由于新疆地区地 形独特, 环境因子的纬度梯度并不明显(表现在乔 木和草地草本植物的一些特征随纬度的变化趋势 相反), 但这并未抹掉植物个体大小、分布区与植物 丰富度的关系, 这可能说明该种关系可以扩展到纬 度和海拔梯度以外。然而, 对于不同的植被类型(森 林和草地), 其关系的强弱不同, 所以, 该关系是否 广泛存在仍需进一步的验证。

另外, Wyszomirski和Weiner (2009)认为种间或 种内物种个体大小的研究同时需要考虑物种生存 的可利用面积, 否则可能会得出一些错误的结论。 除了最常见的分布区和丰富度, 物种个体大小还可 能受到其他因素的影响, 如地下根的分布(Xu et al, 2012)。

基于有限的数据, 本研究对新疆地区森林乔木 
和草地草本植物的个体大小特征进行了研究, 在物 种和区域尺度上分析了其与分布区的关系, 及区域 尺度上个体大小-分布区-丰富度的关系。我们发现 在物种和区域尺度上, 对于森林和草地, 个体大小 与分布区的关系并不完全一致。因此我们认为在区 域尺度上, 由于植被类型/种间作用等, 个体大小和 分布区的关系与简单的单种叠加不同。目前急需一 些更精确并包括更多物种的基础数据库来进行与 植物个体大小相关的研究, 以更深入地了解植物/ 植被的分布特征; 植物个体大小与分布区关系在物 种尺度和区域尺度相异的机制也需要更进一步的 研究。

致谢: 感谢北京大学方精云老师、唐志尧老师、王 志恒老师提供思路和建议, 感谢中国医学科学院药 用植物研究所王丽丽协助补充物种海拔范围数据, 感谢华东师范大学张健老师提供建议。

\section{参考文献}

Aarssen LW (2015) Body size and fitness in plants: revisiting the selection consequences of competition. Perspectives in Plant Ecology, Evolution and Systematics, 17, 236-242.

Aarssen LW, Schamp BS, Pither J (2006) Why are there so many small plants? Implications for species coexistence. Journal of Ecology, 94, 569-580.

Bergmann C (1847) Über die Verhältnisse der Wärmeökonomie der Thiere zu ihrer Grösse. Göttinger Studien, 3, 595-708. (in German)

Bi MJ, Shen MW, Zhou KX, Mao LF, Chen SB, Peng PH (2015) Geographical variance of ladybird morphology and environmental correlates in China. Biodiversity Science, 23, 775-783. (in Chinese with English abstract) [毕孟杰, 沈梦 伟, 周可新, 毛岭峰, 陈圣宾, 彭培好 (2015) 中国㼼虫 体型的地理分异及其与环境因子的关系. 生物多样性, 23, 775-783.]

Blackburn TM, Gaston KJ (1996a) Spatial patterns in the body sizes of bird species in the New World. Oikos, 77, 436-446.

Blackburn TM, Gaston KJ (1996b) Spatial patterns in the geographic range sizes of bird species in the New World. Philosophical Transactions of the Royal Society B: Biological Sciences, 351, 897-912.

Blackburn TM, Hawkins BA (2004) Bergmann's rule and the mammal fauna of northern North America. Ecography, 27, 715-724.

Bowers MA, Brown JH (1982) Body size and coexistence in desert rodents: chance or community structure? Ecology, 63, 391-400.
Brown JH, Maurer BA (1986) Body size, ecological dominance and Cope's rule. Nature, 324, 248-250.

Díaz S, Kattge J, Cornelissen JH, Wright IJ, Lavorel S, Dray S, Reu B, Kleyer M, Wirth C, Prentice IC (2016) The global spectrum of plant form and function. Nature, 529, 167-171.

Dombroskie SL, Aarssen LW (2010) Within-genus size distributions in angiosperms: small is better. Perspectives in Plant Ecology, Evolution and Systematics, 12, 283-293.

Editorial Committee of Chinese Physical Geography of the Chinese Academy of Sciences (1985) Chinese Physical Geography (Pandect). Science Press, Beijing. (in Chinese) [中 国科学院中国自然地理编辑委员会 (1985) 中国自然地 理(总论). 科学出版社, 北京.]

Fang JY, Brown S, Tang YH, Nabuurs GJ, Wang XP, Shen HH (2006) Overestimated biomass carbon pools of the northern mid- and high latitude forests. Climatic Change, 74, 355368.

Fernandez MH, Vrba ES (2005) Body size, biomic specialization and range size of African large mammals. Journal of Biogeography, 32, 1243-1256.

State Forestry Administration, P.R.C. (1989) Xinjiang Forest. China Forestry Publishing House, Beijing. (in Chinese) [中 华人民共和国林业部 (1989) 新疆森林. 中国林业出版 社, 北京.]

Garcia O (2006) Scale and spatial structure effects on tree size distributions: implications for growth and yield modelling. Canadian Journal of Forest Research, 36, 2983-2993.

Gaston KJ, Blackburn TM (1996) Range size-body size relationships: evidence of scale dependence. Oikos, 75, 479485.

Juliano SA (1983) Body size, dispersal ability, and range size in North American species of Brachinus (Coleoptera: Carabidae). The Coleopterists Bulletin, 37, 232-238.

Kuang XJ, Ge F, Xue FS (2015) Geographical variation in body size and sexual size dimorphism in insects. Acta Entomologica Sinica, 58, 351-360. (in Chinese with English abstract) [匡先钜, 戈峰, 薛芳森 (2015) 昆虫体型及性体 型二型性的地理变异. 昆虫学报, 58, 351-360.]

LaBarbera M (1989) Analyzing body size as a factor in ecology and evolution. Annual Review of Ecology and Systematics, 20, 97-117.

Li JF (1991) Climate of Xinjiang. China Meteorological Press, Beijing. (in Chinese) [李江风 (1991) 新疆气候. 气象出版 社, 北京.]

Li LP (2010) Species Richness Patterns of Vascular Plants, Mammals and Birds and Community Structure of Coniferous Forests in Xinjiang, China. PhD dissertation, Peking University, Beijing. (in Chinese with English abstract) [李利 平 (2010) 新疆动植物丰富度分布格局及山地针叶林群 落结构研究. 博士学位论文, 北京大学, 北京.]

Li LP, Jia XH, Yin LK (2017) Vascular plant range size patterns and the relationship with climate and plant richness in Xinjiang region, China. Scientia Sinica Vitae, 47, 314-324. 
(in Chinese with English abstract) [李利平, 贾秀红, 尹林 克 (2017) 新疆植物分布区特征及其与气候和丰富度的 关系. 中国科学: 生命科学, 47, 314-324.]

Li LP, Liu YN, Wang XP, Fang JY, Wang QC, Zhang BG, Xiao PG, Mohammat A, Terwei A (2015) Different effects of regional species pool on plant diversity between forest and grassland biomes in arid northwest China. PLoS ONE, 10, e0131982.

Lu QY, Shen ZH (2009) Altitudinal pattern of species range size of vascular plants in Mt. Shennongjia: a test of Rapoport's rule. Biodiversity Science, 17, 644-651. (in Chinese with English abstract) [卢绮妍, 沈泽昊 (2009) 神农 架海拔梯度上的植物种域分布特征及Rapoport法则检验. 生物多样性, 17, 644-651.]

Madin JS, Lyons SK (2005) Incomplete sampling of geographic ranges weakens or reverses the positive relationship between an animal species' geographic range size and its body size. Evolutionary Ecology Research, 7, 607-617.

Mao LF, Chen SB, Zhang JL, Zhou GS (2016) Altitudinal patterns of maximum plant height on the Tibetan Plateau. Journal of Plant Ecology, doi:10.1093/jpe/rtw128.

McGlone MS, Richardson SJ, Jordan GJ (2010) Comparative biogeography of New Zealand trees: species richness, height, leaf traits and range sizes. New Zealand Journal of Ecology, 34, 137-151.

Mohammat A (2006) Carbon and Nitrogen Storage of Grassland Ecosystem in Xinjiang. PhD dissertation, Peking University, Beijing. (in Chinese with English abstract) [安尼瓦 尔 - 买买提 (2006) 新疆草地生态系统碳、氮储量研究. 博士学位论文, 北京大学, 北京.]

Moles AT, Warton DI, Warman L, Swenson NG, Laffan SW, Zanne AE, Pitman A, Hemmings FA, Leishman MR (2009) Global patterns in plant height. Journal of Ecology, 97, 923-932.

Olson VA, Davies RG, Orme CDL, Thomas GH, Meiri S, Blackburn TM, Gaston KJ, Owens IPF, Bennett PM (2009) Global biogeography and ecology of body size in birds. Ecology Letters, 12, 249-259.

R Core Team (2016) R: a language and environment for statistical computing. R Foundation for Statistical Computing, Vienna, Austria.

Schamp BS, Aarssen LW (2014) Plant species size and density-dependent effects on growth and survival. Journal of Vegetation Science, 25, 657-667.

Schlinkert H, Westphal C, Clough Y, Ludwig M, Kabouw P, Tscharntke T (2015) Feeding damage to plants increases with plant size across 21 Brassicaceae species. Oecologia, $179,455-466$.

Shen ZH, Lu QY (2009) The Rapoport's rule for the geographic patterns of species range size. Biodiversity Science, 17, 560-567. (in Chinese with English abstract) [沈泽昊, 卢绮妍 (2009) 物种分布区范围地理格局的Rapoport法 则. 生物多样性, 17, 560-567.]
Siqueira T, Roque FDO, Trivinho-Strixino S (2008) Species richness, abundance, and body size relationships from a neotropical chironomid assemblage: looking for patterns. Basic and Applied Ecology, 9, 606-612.

Stevens GC (1989) The latitudinal gradient in geographical range: how so many species coexist in the tropics. The American Naturalist, 133, 240-256.

Thompson K, Gaston KJ, Band SR (1999) Range size, dispersal and niche breadth in the herbaceous flora of central England. Journal of Ecology, 87, 150-155.

Tracey AJ, Aarssen LW (2011) Competition and body size in plants: the between-species trade-off for maximum potential versus minimum reproductive threshold size. Journal of Plant Ecology, 4, 115-122.

Tracey AJ, Aarssen LW (2014) Revising traditional theory on the link between plant body size and fitness under competition: evidence from old-field vegetation. Ecology and Evolution, 4, 959-967.

Tracey AJ, Stephens KA, Schamp BS, Aarssen LW (2016) What does body size mean, from the "plant's eye view"? Ecology and Evolution, 6, 7344-7351.

Wang L, Chen KK, Cui DF, Xu Z, Liao K, Zhao YS, Zhou L (2006) Study on the vegetation and diversity characteristics of Prunus divaricata Form. in western Tianshan Mountains of Xinjiang Province. Arid Land Geography, 29, 850-855. (in Chinese with English abstract) [王否，陈考科，崔大方， 许正, 廖康, 赵永生, 周龙 (2006) 新疆西天山野樱桃李 植物群落类型(群系)及物种多样性分析. 干旱区地理, 29 , $850-855$.

Wang XH (2006) Phytogeography and Species Diversity of Typical Evergreen Broad-Leaved Forest in China. PhD dissertation, East China Normal University, Shanghai. (in Chinese with English abstract) [王希华 (2006) 中国典型常绿 阔叶林植物地理与物种多样性研究. 博士学位论文, 华 东师范大学, 上海.]

Waugh JM, Aarssen LW (2012) Size distributions and dispersions along a 485 -year chronosequence for sand dune vegetation. Ecology and Evolution, 2, 719-726.

Weiner J, Thomas SC (1986) Size variability and competition in plant monocultures. Oikos, 47, 211-222.

White EP, Ernest SKM, Kerkhoff AJ, Enquist BJ (2007) Relationships between body size and abundance in ecology. Trends in Ecology and Evolution, 22, 323-330.

Willig MR, Patterson BD, Stevens RD (2003) Patterns of range size, richness, and body size in the Chiroptera. In: Bat Ecology (eds Kunz TH, Fenton MB), pp. 580-621. University of Chicago Press, Chicago.

Wilson C, Gurevitch J (1995) Plant size and spatial pattern in a natural population of Myosotis micrantha. Journal of Vegetation Science, 6, 847-852.

Woodward G, Ebenman B, Emmerson M, Montoya JM, Olesen JM, Valido A, Warren PH (2005) Body size in ecological networks. Trends in Ecology and Evolution, 20, 402-409. 
Wyszomirski T, Weiner J (2009) Variation in local density results in a positive correlation between plant neighbor sizes. The American Naturalist, 173, 705-708.

Xu C, Zhang MJ, Liu MS, An SQ, Sheng S (2012) Interspecific effects on plant size inequality: evidence from a temperate savanna community. Plant Ecology, 213, 225-235.
Zhang J, Nielsen SE, Mao LF, Chen SB, Svenning JC (2016) Regional and historical factors supplement current climate in shaping global forest canopy height. Journal of Ecology, 104, 469-478.

\section{(责任编委：陈圣宾 责任编辑：黄祥忠)}

\section{附录 Supplementary Material}

附录1 区域尺度森林乔木和草地草本植物平均个体大小与物种分布经纬度的关系 $\left(0.2^{\circ} \times 0.2^{\circ}\right.$ 分辨率 $)$

Appendix 1 Relationship of plant body size and the geographic distributions (indicated by the median values of the midpoint of the latitude and longitude of all plants in a grid cell) in the regional scale (With $0.2^{\circ} \times 0.2^{\circ}$ grid cell)

http://www.biodiversity-science.net/fileup/PDF/2016336-1.pdf

附录2 区域尺度森林乔木和草地草本植物个体大小与分布区特征(分布区面积、东西分布幅度、南北分布幅度)的关系(自然 对数, $0.2^{\circ} \times 0.2^{\circ}$ 分辨率)

Appendix 2 Relationship of plant body size and range size (range area, extent North-South and extent East-West) in the regional scale (with logarithmic scale, $0.2^{\circ} \times 0.2^{\circ}$ grid cell)

http://www.biodiversity-science.net/fileup/PDF/2016336-2.pdf

附录3 区域尺度森林乔木和草地草本植物个体大小与物种丰富度的关系 (自然对数, $0.2^{\circ} \times 0.2^{\circ}$ 分辨率)

Appendix 3 Relationship of plant body size and regional species richness (with logarithmic scale, $0.2^{\circ} \times 0.2^{\circ}$ grid cell) http://www.biodiversity-science.net/fileup/PDF/2016336-3.pdf 

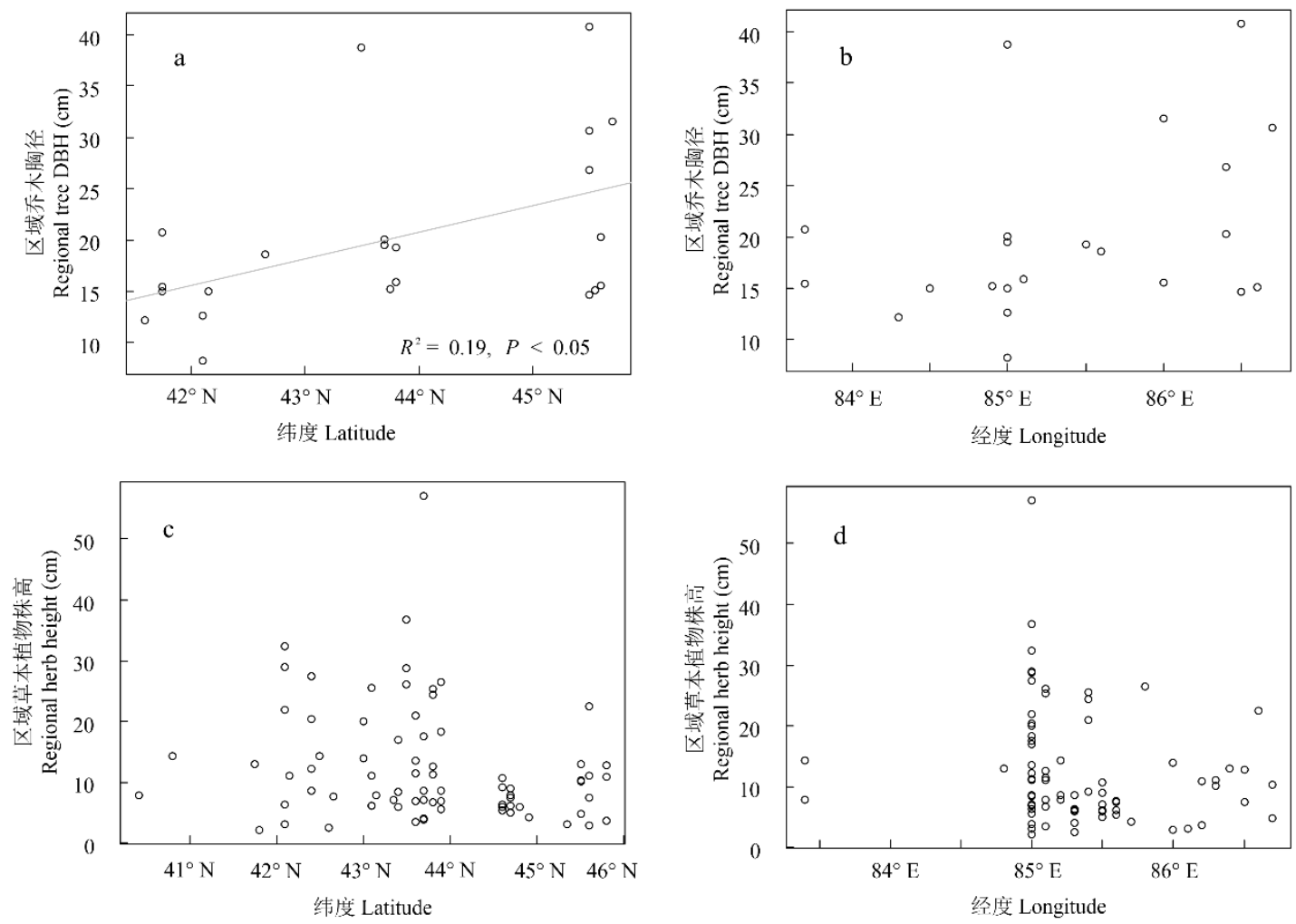

附录1 区域尺度森林乔木和草地草本植物平均个体大小与物种分布经纬度的关系 $\left(0.2^{\circ} \times 0.2^{\circ}\right.$ 分辨率 $)$

Appendix 1 Relationship of plant body size and the geographic distributions (indicated by the median values of the midpoint of the latitude and longitude of all plants in a grid cell) in the regional scale (with $0.2^{\circ} \times 0.2^{\circ}$ grid cell) 
李利平, 安尼瓦尔 - 买买提, 努尔巴依・阿布都沙力克, 努尔佳玛丽・沙尔巴依, 万华伟. 新疆山地森林乔木 和草地草本植物个体大小分布特征. 生物多样性, 2017, 25 (11): 1202-1212.

http://www.biodiversity-science.net/CN/10.17520/biods.2016336
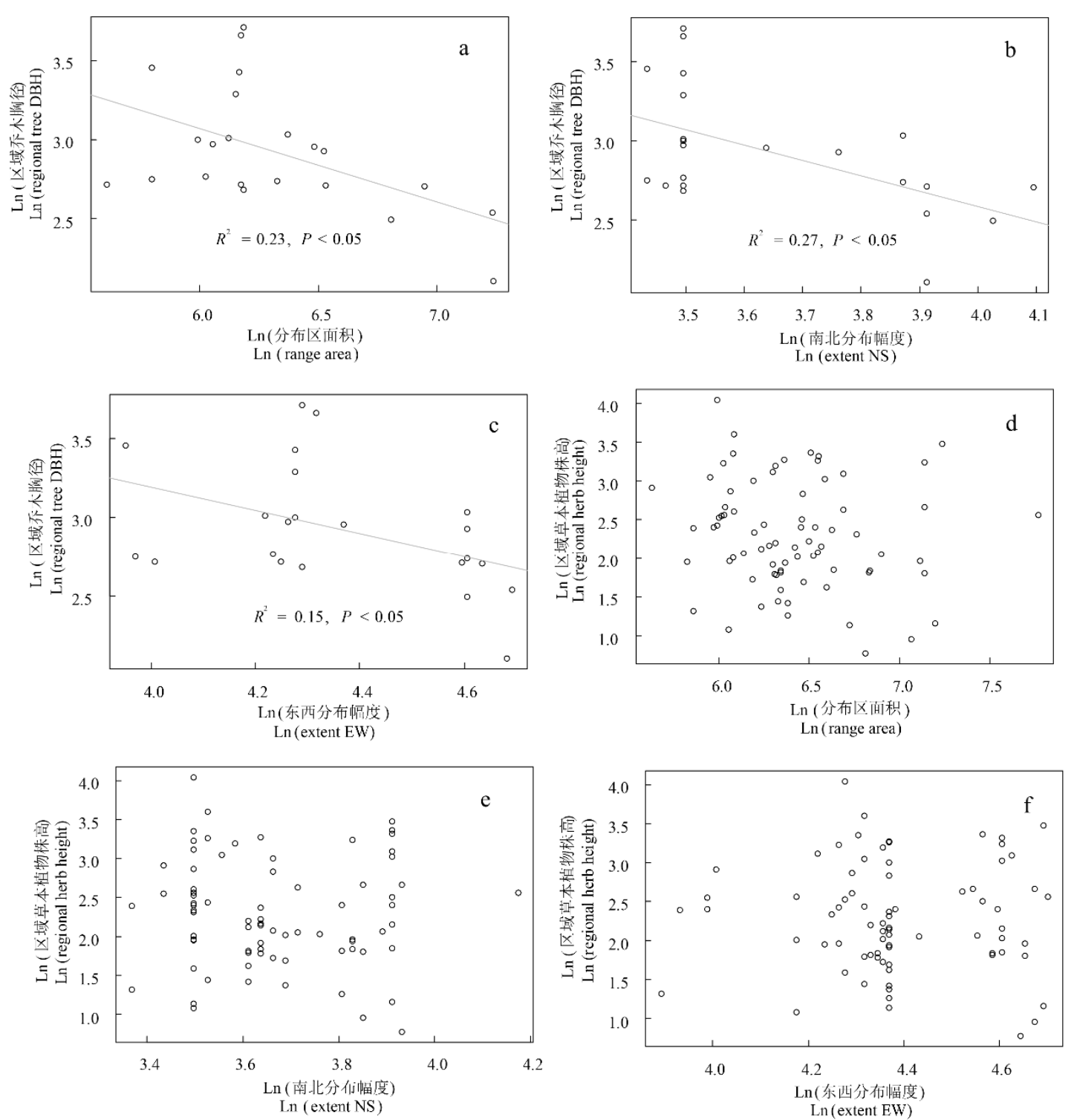

附录2 区域尺度森林乔木和草地草本植物个体大小与分布区特征 $($ 分布区面积、东西分布幅度、南北分布 幅度)的关系(自然对数, $0.2^{\circ} \times 0.2^{\circ}$ 分辨率)

Appendix 2 Relationship of plant body size and range size (range area, extent North-South (extent NS) and extent East-West (extent EW)) in the regional scale (with logarithmic scale, $0.2^{\circ} \times 0.2^{\circ}$ grid cell) 
李利平, 安尼瓦尔 - 买买提, 努尔巴依・阿布都沙力克, 努尔佳玛丽・沙尔巴依, 万华伟. 新疆山地森林乔木 和草地草本植物个体大小分布特征. 生物多样性, 2017, 25 (11): 1202-1212.

http://www.biodiversity-science.net/CN/10.17520/biods.2016336
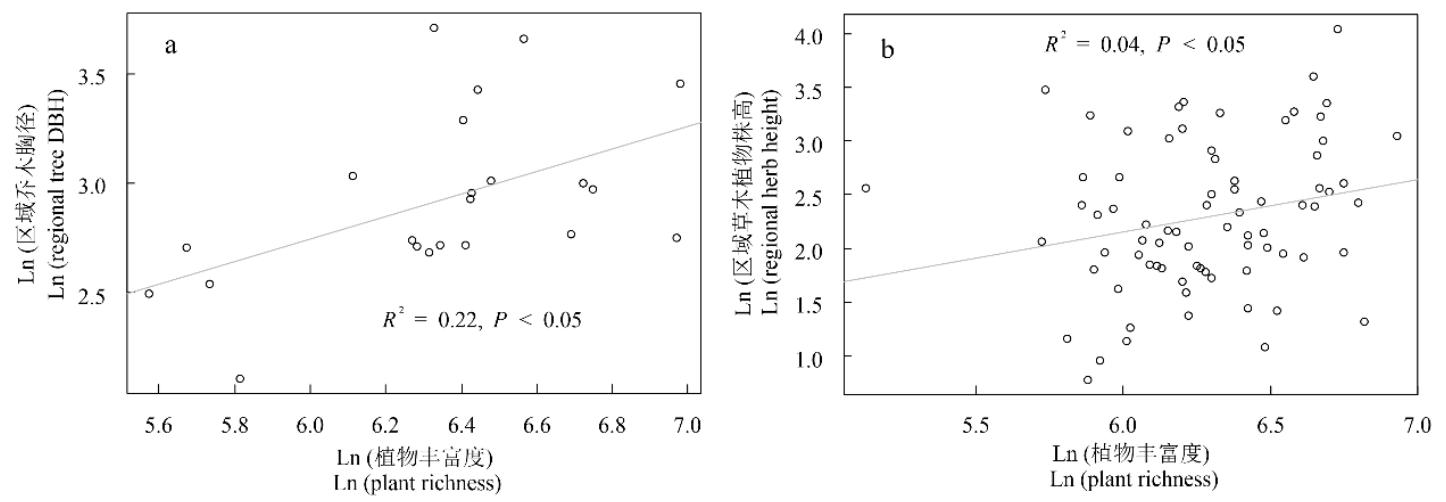

附录3 区域尺度森林乔木和草地草本植物个体大小与物种丰富度的关系 (自然对数, $0.2^{\circ} \times 0.2^{\circ}$ 分辨率)

Appendix 3 Relationship of plant body size and regional species richness (with logarithmic scale, $0.2^{\circ} \times 0.2^{\circ}$ grid cell) 